Reprod. Nutr. Dévelop., 1981, 21 (2), 265-277.

\title{
The extent and nature of protein degradation in the tissues during development
}

\author{
par D. J. MILLWARD, P. C. BATES, S. ROSOCHACKI
}

Clinical Nutrition and Metabolism Unit, Dept. of Human Nutrition, London School of Hygiene and Tropical Medicine,

4 St. Pancras Way, London NW1 2PE, U. K.

Summary. Protein turnover, defined as the degradation and replacement of proteins, appears to vary between most adult species in the same way as metabolic rate, i.e. as $W^{0.75}$, although it may be a little lower in man. During development in the rat it also varies as metabolic rate. Thus $P$ Total $=14.7 \mathrm{~W}_{\mathrm{kg}}^{0,53}$ per day. Most of this turnover occurs in nonmuscle tissues $\left(P=11.3 W_{\mathrm{kg}}^{0.50}\right.$ per day) with protein turnover in muscle described by $P=3.53 \mathrm{~W}_{\mathrm{kg}}^{0.69}$ per day. Mechanisms for protein degradation in liver and muscle involve lysosomes although the morphology of the lysosomal system in muscle is different from that in liver. However, heterogeneous turnover is a feature of proteins in both tissues including the principal myofibrillar proteins. While the reaction order of protein synthesis can reasonably be described as zero order - a fixed rafe per unit of DNA - there is less certainty about degradation. It is postulated that structural and functional characteristics of the cytoplasm of cells determine the accessibility of cellular protein to the degrading system. As a result, a first order rate for a particular cell type is fixed, and this determines the magnitude of the protein-DNA ratio or the functional-cell size. The first order degradation rate of the cytoplasmic protein also determines the specific activity of the degrading enzymes.

\section{Infroduction.}

Protein turnover is a phenomenon common to most cells and comprises 2 processes : protein degradation and protein synthesis. It can be argued that any examination of protein turnover should start with the process of protein degradation since if is this process which creates the need for protein resynthesis and results in the phenomenon of protein turnover. The study of protein degradation however is complicated by the fact that in comparison to protein synthesis, its mechanism is less well understood and its rate is more difficult to measure. This is particularly true for those of us interested in the regulation of protein turnover in vivo. Probably the only method available to assess the rate of protein degradation in the whole body or in individual tissues in vivo is the indirect one of calculating degradation as the difference between measured rates of protein synthesis and net change in protein mass. This is the replacement rate of protein synthesis, and there is no inherant reason why this calculation should not be accurate as long as the measurements of protein synthesis and rates of net change 
in protein mass are accurate. This method does have the advantage of providing a complete description of the process of protein turnover. However, there can be difficulties in terminology as a result of this approach because the method measures only the replacement rate of protein synthesis and, although this is equal to the rate of degradation, it is obviously a different process. In this paper the problem will be solved by the use of the general term « protein turnover » which is defined as the replacement rate of protein. In growing animals this is equal to the rate of protein degradation and less than the rate of protein synthesis, but in animals losing protein the rate of protein furnover will be equal to the rate of protein synthesis and less than the rate of protein degradation.

\section{The extent of protein turnover in the whole body.}

Two important questions which can be asked about the extent of protein turnover are how: does it vary between species, and how does it change within a species during

\section{TABLE 1}

Protein furnover in adults of different species and in the rat during development

1 A Mature animals (')

\begin{tabular}{|c|c|c|c|}
\hline Species & $\begin{array}{c}\text { Body weight } \\
\mathrm{kg}\end{array}$ & $\begin{array}{l}\text { Protein } \\
\text { g/d }\end{array}$ & $\begin{array}{l}\text { urnover } \\
g / w^{0.75} / \mathrm{d}\end{array}$ \\
\hline $\begin{array}{l}\text { Rat } \ldots \ldots \ldots \\
\text { Rabbit } \ldots \ldots . \\
\text { Sheep } \ldots \ldots \\
\text { Man ........ } \\
\text { Cattle } \ldots \ldots\end{array}$ & $\begin{array}{l}0.350 \\
3.6 \\
63 \\
67 \\
500\end{array}$ & $\begin{array}{c}7.7 \\
39 \\
351 \\
194 \\
1700\end{array}$ & $\begin{array}{c}16.7 \\
15.0 \\
15.7 \\
8.28 \\
16.1\end{array}$ \\
\hline
\end{tabular}

1 B Rat during development $\left({ }^{2}\right)$

\begin{tabular}{|c|c|c|c|c|c|c|c|c|}
\hline \multirow{3}{*}{$\begin{array}{l}\text { Body } \\
\text { weight } \\
\text { g }\end{array}$} & \multicolumn{2}{|c|}{ Whole body } & \multicolumn{3}{|c|}{ Muscle } & \multicolumn{3}{|c|}{ Non Muscle } \\
\hline & \multirow{2}{*}{$\begin{array}{l}\text { protein } \\
\mathbf{g}\end{array}$} & \multirow{2}{*}{$\begin{array}{l}\text { furnover } \\
\text { p. } 100 / \mathrm{d}\end{array}$} & \multirow{2}{*}{$\begin{array}{l}\text { protein } \\
\mathbf{g}\end{array}$} & \multicolumn{2}{|c|}{ furnover } & \multirow{2}{*}{$\begin{array}{l}\text { protein } \\
g\end{array}$} & \multicolumn{2}{|c|}{ turnover } \\
\hline & & & & p. $100 / d$ & p. 100 total & & p. $100 / d$ & p. 100 total \\
\hline $\begin{array}{r}37 \\
115 \\
510\end{array}$ & $\begin{array}{r}5.9 \\
18.4 \\
81.6\end{array}$ & $\begin{array}{l}43.4 \\
23.3 \\
12.6\end{array}$ & $\begin{array}{c}1.63 \\
7.39 \\
48.2\end{array}$ & $\begin{array}{l}22.5 \\
9.8 \\
4.6\end{array}$ & $\begin{array}{l}14 \\
17 \\
21\end{array}$ & $\begin{array}{r}4.29 \\
11.01 \\
33.4\end{array}$ & $\begin{array}{l}51 \\
32 \\
24\end{array}$ & $\begin{array}{l}85 \\
83 \\
78\end{array}$ \\
\hline
\end{tabular}

(1) Values taken from Reeds and Lobley (1980), except for the value for man, taken from the unpublished results of D. G. A. Clugston. All values calculated from the leucine flux, determined by constant infusion of $\left(1{ }^{14} \mathrm{C}\right)$ leucine, corrected for leucine oxidation.

(2) Values of Millward ef al., (1975) and unpublished data. Measurements of protein furnover in muscle (gastrocnemius and quadriceps) and whole body were made by constantinfusion of ${ }^{14} \mathrm{C}$-tyrosine (see Waterlow ef al., 1978). Protein turnover is used here to describe the replacement rate of protein furnover (i.e. synthesisgrowth). Protein content of the whole body (measured as non-collagen protein) was equal to $16 \mathrm{p}$. 100 wet weight. Muscle protein content was calculated from the combined data of Miller (1968) for muscle mass and Millward et al. (1975) for muscle protein concentration. Non-muscle protein and protein furnover was calculated as the difference between muscle and whole-body protein contents and protein-furnover rates. 
development? As far as the first of the questions is concerned, several reviewers have concluded that in mature animals the rate of protein turnover is a constant function of body weight to the power 0.75 (i.e. W0.75) (Waterlow, Garlick and Millward, 1978 ; Garlick, 1980 ; Reeds and Lobley, 1980). This means that protein turnover varies between species in the same way as the metabolic rate. A collection of data is shown in table 1a. When this data is examined more closely however it would appear that the value for man is lower than that for other species both smaller and larger. However the data for farm animals is still rather limifed. It would be very surprising if such factors as the presence of the rumen and milk production did not affect whole body turnover.

The way in which protein turnover changes during development in the rat is shown (for one strain) in table $1 b$. These results are derived from measurements of the whole body tyrosine flux obtained with the constant infusion method (Waterlow, Garlick and Millward, 1978). They are quite similar to those reported by Reeds and Lobley (1980).

At weaning, the whole body turnover rate is very high (43 p. 100 per day) and falls to only 12.6 p. 100 per day at 1 year of age. The mechanism of these changes, in terms of variation of the rate in the different tissues and organs of the body, is not well documented. As a first step in explaining the pattern of developmental changes, the rate for the whole body can be divided into two compartments of muscle and nonmuscle tissues, since there is good data on the changes in muscle protein turnover during development.

The data in table $1 b$ shows that in the rat most of the protein turnover occurs in non-muscle tissues (i.e. about 80 p. 100), and this does not change much throughout development. A more precise analysis of the relationship between protein furnover in these two compartments and body weight can be done by examining the relationship on a double-log basis. Because this is linear, this means that protein turnover (P) is related to body weight $(W)$ according to the equation $P=a W^{b}$, where $a$ and $b$ are constants. Thus protein turnover in the whole body, muscle and non-muscle is related to body weight according to the equations

$$
\begin{aligned}
& P_{\text {Total }}=14.7 \mathrm{~W}_{\mathrm{kg}}^{0.53} \mathrm{~g} \text { protein/day } \\
& \mathrm{P}_{\text {Non-muscle }}=11.3 \mathrm{~W}_{\mathrm{kg}}^{0.50} \mathrm{~g} \text { protein/day } \\
& \mathrm{P}_{\text {Muscle }}=3.53 \mathrm{~W}_{\mathrm{kg}}^{0.69} \mathrm{~g} \text { protein/day }
\end{aligned}
$$

This means that with increasing body size during development the fall in the intensity of whole body protein turnover (i.e. the rate per unit body weight) is more marked than the fall with increasing body size of mature animals of different species. This is also true of developmental changes in metabolic rate. It was shown many years ago that in the pig, fasting heat production varies as $W^{0.56}$ (Breirem, 1939) and, in man between $10-70 \mathrm{~kg}$ body weight, the resting metabolic rate reported by Talbot (1938) can be shown to vary as W0.59.

There are two possible explanations for these developmental changes in the intensity of protein turnover in the whole body. Changes can occur in body composition affecting the relative amounts of tissues and organs with different turnover rates, and changes can occur in the rate within individual tissues and organs with development. 
In muscle developmental changes in the rate of protein turnover have been demonstrated in lambs (Arnal, Ferrara and Fauconneau, 1976); chicks (Narayan and Eapen 1974 ; Maruyama, Sunde and Swick, 1978) as well as in the rat (Millward ef al., 1975). The pattern of this developmental change may vary between muscles and the rate in individual muscles at maturity varies, being highest in slow contracting red muscles (Millward, 1980b). In the rat (table 1b) the developmental fall in total muscle protein turnover reflects the combination of a marked fall in the rate of turnover (from 22 to $4.6 \mathrm{p} .100 \mathrm{~d}^{-1}$ ) and an increase in the relative amount of muscle tissue protein (from 27 to $59 \mathrm{p} .100$ of total body protein). Thus during development, the fall in the overall rate of muscle protein turnover per unit body weight is less than the fall in the intensity (i.e. the fractional rate) in the individual muscle.

In contrast, in the non-muscle compartment the development fall in the overall rate of protein turnover is more marked than the fall in the intensity (from 51 to $24 \mathrm{p} .100$ $d^{-1}$ ) in this compartment because in this case the relative size of the compartment falls during development (from 73 to 43 p. 100 of total body protein). Thus the mechanism of the developmental changes are different within the two compartments. However, there is not much information about changes in the relative organ sizes and rates of protein turnover in individual non-muscle tissues which together make up this compartment. What data there is would suggest that developmental changes in the rate of protein turnover in liver and kidney are minimal, and that in brain the rate falls by 40 p. 100 between 100 and $700 \mathrm{~g}$ body weight (Waterlow, Garlick and Millward, 1978). This it is possible that the $50 \mathrm{p} .100$ fall in intensity of protein turnover in the non-muscle compartment could reflect changes in the relative amount of individual organs rather than changes within organs. Obviously more information is needed.

\section{The nature of protein degradation in the tissues.}

a) Mechanism of degradation in liver and muscle.

The detailed mechanisms by which active proteins are degraded to individual amino acids has proved to be very difficult to determine, although as a result of considerable effort over the last decade possible mechanisms are beginning to emerge (Goldberg and Dice, 1974 ; Goldberg and St John, 1976 ; Ballard, 1977 ; Waterlow, Garlick and Millward, 1978 ; Dean, 1980 ; Millward, 1980b). The process is best understood in liver and a scheme for degradation involving the lysosome is shown in figure 1. The experimental work on which this scheme is based is described in full eleswhere (Millward, 1980b). The scheme allows for specific and non-specific innactivating mechanisms which direct proteins towards the lysosome which they enter through a mechanism of micropinocytosis. Thus heterogeneity of turnover is achieved through a combination fof the various innactivating mechanisms and through variability in the binding affinity of individual protein subunits with the lysosomal membrane. While all now accept the importance of the lysosome in hepatic protein degradation, the major arguments concern the nature and extent of non-lysosomal systems (Ballard, 1977). A possible component of the non-lysosomal system is the alkaline protease descrived by De Martino and Goldberg (1979).

In skeletal muscle much less is known. However there is sufficient information 


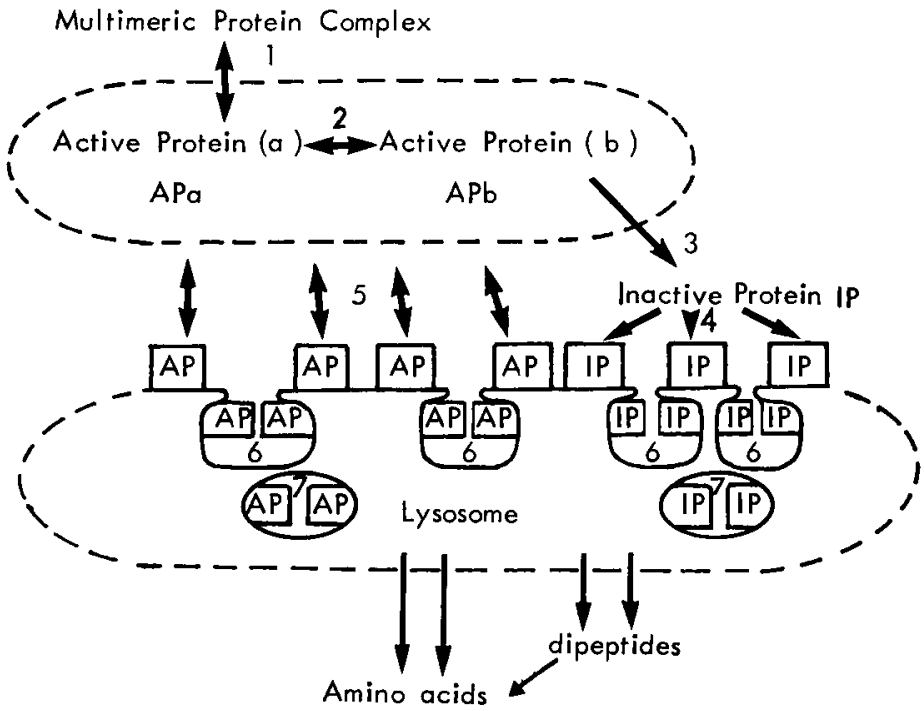

FIG. 1. - Protein degradation in liver.

Step 1 : Multimeric protein complexes are in equilibrium with individual proteins and subunits. Step 2 : For some proteins a reversible transformation induced by substrafe, coenzyme or other ligand binding converts the protein to a form which is susceptible to a specific or semi-specific irreversible inactivating step (3). This inactive protein binds to the lysosomal membrane (4). Step 5 : active proteins in any conformation bind reversibly on contact with the lysosomal membrane, and remain in contact for varying lengths of time according to their binding affinities which are inherant properties of the protein subunit. Step 6 : micropinocytosis sequestrates membrane and membranebound proteins (logether with soluble proteins) so that the rate of sequestration will be greater for those proteins which show highest affinities for membrane binding. Step 7 : the sequestered vesicle is degraded (or perhaps partially degraded with some membrane recycling to the exterior), exposing the protein to the range of proteinases. Free amino acids are very rapidly formed which leave the lysosome, together with some dipeptides, to be hydrolysed in the cytoplasm.

In addition to this mechanism for sequestration of protein, an autophagic vacuole may form around the complete multimeric protein complex or organelle leading to its complete degradation (adapted from Millward 1980b).

to suggest that in several respects the degradative system is similar to that of the liver. The soluble proteins show the same relationship between various physicochemical properties and their degradation rate as observed in liver and other tissues (Millward, 1980b). Thus large, acidic, hydrophobic proteins tend to be degraded more rapidly. The extent to which individual proteins of the myofibril turnover at different rates remains controversial. Thus many studies indicate heterogeneity of turnover with actin generally (though not always) being slower than myosin (Waterlow, Garlick and Millward, 1978). However, recently Lobley and Lovie (1979) argued that the apparent heterogeneity of turnover of myofibrillar proteins was an artefact of imperfect methodologies and that actin and myosin synthesis rates are the same. However, in this study the authors measured relative synthesis rates in growing animals (rabbits), and there is evidence that relative synthesis rates of protein tend to be similar when growth is occurring (in the fed state), even when differences are apparent in the steady 
state (after an overnight fast ; Bates and Millward, 1978). Our own measurements of actin and myosin heavy-chain turnover in the rat indicate that actin is replaced at a much slower rate than myosin heavy-chain (table 2 ). Also in smooth muscle actin

TABLE 2

Relative rates of replacement of aldolase, actin and myosin heavy-chain in rat skelefal muscle (1)

\begin{tabular}{lll}
\hline & \multicolumn{2}{c}{$\begin{array}{c}\text { Replacement rate } \\
\text { p. 100/d (SD) }\end{array}$} \\
\hline Aldolase $\ldots \ldots \ldots \ldots \ldots \ldots$ & 9.3 & $(2.5)$ \\
Myosin heavy-chain $\ldots \ldots \ldots$ & 6.7 & $(2.0)$ \\
Actin $\ldots \ldots \ldots \ldots \ldots \ldots \ldots$ & 2.7 & $(2.0)$ \\
Mixed Muscle $\ldots \ldots \ldots \ldots \ldots$ & 8.5 & $(1.5)$ \\
\hline
\end{tabular}

(1) Results of Millwart, Bates and Sparrow (unpublished). Replacement rates were measured in $100 \mathrm{~g}$ rats in the steady state (after an overnight fast). $\left({ }^{14} \mathrm{C}\right.$-methyl) methionine and $\left({ }^{14} \mathrm{C}\right)$ tyrosine were injected into eighteen rats and individual animals were killed at various times up to $60 \mathrm{~min}$, at which time 6 rats were killed. Measurements were made of the specific radioactivity of S-adenosyl methionine in the acid soluble pool of muscle, of tyrosine in the acid soluble pool and in aldolase and mixed muscle protein, of trimethyllysine isolated from myosin heavy chain and of 3-methylhistidine isolated from actin. Replacement rates were calculated from the labelling of the various residues in the profeins divided by the area under the precursor specific radioactivity-time course (i. e. S-adenosyl methionine for trimethyl lysine and 3-methylhistidine, and tyrosine for aldolase and mixed protein).

appears to be degraded more slowly than the overall rate of degradation (Millward ef al., 1980). Thus the case for heterogeneity of turnover of myofibrillar proteins is strong.

Another similarity between the degradative system in muscle and in liver is the involvement of the acid proteinases, particularly cathepsin B and D (Bird et al., 1980). As well as the fact that these proteases have been visualized in muscle cell lysosomes (Bird et al., 1980), their relative specific activities in different muscle types vary in the same way as the overall degradation rates (Millward, 1980b). Furthermore, marked changes in the acid proteinase activities occur when changes in muscle protein degradation occur. Some examples are given in table 3 (Rosochacki and Millward, unpublished information).

One possible difference between muscle and other tissues is the potential involvement of calcium in the regulation of degradation through the calcium-activated neutral protease (CAF) (Bird et al., 1980 ; Millward, 1980b). This enzyme appears to initiate disruption of the myofibrillar matrix when calcium levels are abnormally high in injured or pathological muscle. This is achieved by removal of the Z-disc possibly by degrading a protein which is involved with the $\alpha$-actinin in the Z-disc. There is as yet no evidence that this enzyme is involved in normal muscle degradation. Furthermore, the activity in different muscles does not vary with the degradation rate, being higher in the slow turning-over posterior latissimus dorsi muscle than in the fast furningover anterior latissimus dorsi (Millward, 1980b).

Another difference between the degradative process in muscle and that in liver is the morphology of the lysosomal system. Most authors agree that, apart from the cytoplasm immediately adjacent to the nuclei on the periphery of the myofibre, conventional lysosomes are seldom observed within the intermyofibrillar space. Indeed some investigators report they have never observed them (Christie and Stoward, 1977). 
Recent measurements of the localisation of acid phosphatase (Christie and Stoward, 1977 ; Trout, Stauber and Schottelius, 1979 ; Cambell, 1979) appear to indicate that this enzyme, usually accepted as a constituent of lysosomes, is distributed throughout the sarcoplasmic reticulum. Thut it is possible that in contrast to the liver, where lysosomal hydrolases synthesized on ribosomes bound to the endoplasmic reticulum (ER) are transferred to discrete lysosomes through the ER-Golgi system, muscle hydrolases may be discharged after synthesis into specialised parts of the sarcoplasmic reticulum. If this is the case, then the role of the sarcoplasmic reticulum in muscle must be extended to include protein degradation (as well as its role in the regulation of cytoplasmic calcium concentration).

Any mechanism of myofibrillar degradation must therefore take into account both the helerogeneity of myofibrillar degradation and an intermyofibrillar location of the degradation system. A recent proposal is shown in figure 2 (Millward, 1980b).

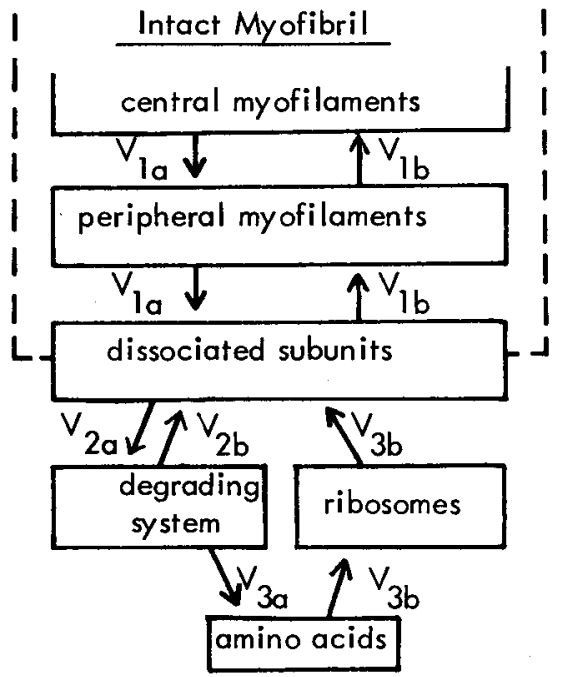

FIG. 2. - Scheme for myofibrillar protein turnover.

Individual subunits of the various contractile protein exchange between myofilaments (perhaps aided by the cytoplasmic flow of each contraction cycle) $\left(V_{1 a, b}\right)$. Subunits mainly from peripheral myofilaments can interact reversibly with a degrading system (probably lysosomal) located in the sarcotubular system of the intermyofibrillar space $\left(V_{2 a, b}\right)$. Some subunits are taken up and degraded by the system $\left(V_{2 a}-V_{2 b}=V_{3 a}\right)$ to be replaced by newly synthesized sub-units $\left(V_{3 b}\right)$. These become incorporated into peripheral myofilaments initially but will subsequently become distributed throughout the myofibril (adapted from Millward, 1980b).

Individual protein subunits of the myofilaments continously exchange with each other. Those on peripheral myofilaments are most likely to interact with the degradative system located in the intermyofibrillar space where they can be degraded. At the same time, new proteins on ribosomes in the intermyofibrillar space can be added to myofilaments initially on the myofibrillar-periphery (Morkin, 1970). These eventually become distributed throughout the myofibrillar matrix. The experimental evidence on which this is based is discussed in Millward (1980b). 
b) Regulation of the rate of protein degradation.

As far as muscle is concerned, the regulation of degradation in response to changes in nutritional and hormonal factors and to exercise has recently been reviewed (Millward ef al., 1980a). Here the problem is to account for the differences in the rates in various mature muscles, the changes which occur during development in muscle, and why the rate should be generally lower in muscle than in other tissues such as the liver.

In general there are two mechanisms by which changes in the rate of degradation can occur. A change can occur in either the capacity or activity of the degrading system or in the susceptibility of the substrate. As far as the first of these possibilities is concerned, there are numerous examples of changes in the morphology and osmotic fragility of lysosomes in liver in a variety of condifions (Mortimore, 1980), and changes have been observed in the concentration of proteinases in muscle as shown in table 3

TABLE 3

Changes in cathepsin D activity and protein degradation rate in rat skelefal muscle in various conditions

Cathepsin D

( $\mu$ g tyrosine/g muscle protein per $\mathrm{h}$ )

Degradation rate

(a) Developmental changes

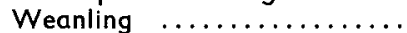

Adult .................

28.1

21.8

30.9

19.6

24.9

30.2

23.5

18.0

23.8 high

low

high

low

low

high

reduced normalised

Thyroidectomy $+\mathrm{T}_{3} \ldots \ldots \ldots$

Cathepsin $D$ activity measured as the total pepstatin-sensitive activity toward haemoglobin at $\mathrm{pH} 3.75$ in the presence of 0.2 p. 100 Triton $X-100$.

Changes in degradation rate in groups $(a-c)$ as reported in Millward ef al. (1975) and in group (d) in Brown and Millward (1980).

(Rosochacki and Millward, 1979 ; Millward et al., 1980a). This would imply that the machinery of protein degradation is responsive to regulatory factors. Different concentrations of proteinases would appear to be responsible for the differences in the rates in different muscle types (Millward, 1980b). Judging by the developmental fall in the activity of alkaline phosphatase in muscle, the specific activity of the degrading system would also appear to be responsible, at least in part, for the changes in degradation during development (Cambell, 1980).

As far as the susceptibility of the substrate to the degradative system is concerned, 
this is not easy to measure. Because protein degradation is increased in growing muscles during normal growth (Millward et al., 1975) or induced hypertrophy (Laurent and Millward, 1980), it has been postulated that the increase in the number and size of myofibrills alters the susceptibility of the contractile protein, increasing the rate of degradation by some as yet not understood mechanism. This increased degradation has been called « wastage » (Laurent and Millward 1980 ; Millward, 1980a).

If has also been argued that he higher degradation rate in a tonic muscle, such as the anterior latissimus dorsi muscle of the fowl, may reflect the fact that in this muscle the myofibrillar structure is «looser 》 (Page, 1969) making it more susceptible to degradation than the posterior latissimus dorsi muscle (Laurent, Sparrow and Millward, 1978). Thus the characteristic structure and function of the myofibrillar matrix would in some, as yet poorly defined, way determine its susceptibility to degradation.

The problem in understanding the differences in the rates of degradation between muscles becomes one of deciding whether the relative specific activity of the degrading system or the relative susceptibility of the substrate is the determining factor. This problem is an important one because it relates to the question of the kinetic order of the process of protein degradation at the level of the whole cell.

As far as the furnover of individual proteins is concerned, it has long been argued (Schimke, 1970) that protein synthesis is a zero order process (i.e. occurring at a fixed absolute rate, S), protein degradation is a first order process (i. e. occurring at a fixed fractional rate, $k d$, so that the absolute rate varies with the mass of the protein) and that the amount of the protein $(M)$ is determined according to the equation

$$
M=\frac{S}{k d} \text {. }
$$

It has been suggested that we can use a similar expression to describe the amount of protein associated with each diploid nucleus, i.e. the protein-DNA ratio (Millward, 1978 ; Waterlow, Garlick and Millward, 1978 ; Millward 1980a). Measurements of the rate of protein synthesis in different muscles and in the liver indicate that, although the fractional rates vary, the rate of synthesis per unit of DNA is not significantly different between different muscles and, more importantly, not very different in liver. As a result, the concept has been developed of "nuclear management » of an amount of cytoplasm through this fixed rate of protein synthesis. It is probably most appropriate to refer to the protein-DNA ratio as the «functional cell size » since this avoids the problem resulting from the fact that, in muscle, the morphologically defined cell is multinucleate and, in liver, many hepatocytes are polyploid. In other words, Cheek's DNA-unit (Cheek et al., 1971) is extended to all cell types and is redefined as the " functional cell size » which is the amount of cytoplasmic protein managed by each diploid nucleus. If protein synthesis is zero order at the level of the functional cell - a fixed rate per unit DNA $(\mathrm{Sn})$ - then the functional cell size $(\mathrm{Mn})$ would be determined by the degradation rate if it was a first-order process $(k d)$

$$
\mathrm{Mn}=\frac{\mathrm{Sn}}{\mathrm{kd}} .
$$

Our measurements in the rat and fowl (Waterlow, Garlick and Millward, 1978 ; Millward, 1980a) indicate that for tissues which contain relatively few inactive cell 
types, such as skeletal muscle and liver, the relationship holds (except that $\mathrm{Sn}$ is higher in fowl than in rat, probably as a result of a higher body temperature in the fowl - Laurent, Sparrow and Millward, 1978).

As discussed above, this relationship depends crucially on the kinefic order of the reactions of protein synthesis and degradation and, while zero order protein synthesis is conceptually a reasonable assumption, the order of the degradation reaction is more equivocal. Thus some characteristic of the cytoplasmic protein as a whole must determine its susceptibility to degradation. This characteristic may be the particular cytoplasmic structure. For example, a major difference between a muscle cell and a hepatocyte is the fact that in muscle 70 p. 100 of the cytoplasmic protein is tightly bound within the myofibril. This is true for not only contractile proteins but also for proteins such as aldolase which is bound to the thin filament (Walsh ef al., 1980). Assuming, that the degrading system is part of the sarcoplasmic reticulum in the intermyofibrillar space, there is a separation of substrate and degrading system, and factors which affect the binding of individual proteins to the myofibril would regulate this separation. In contrast, in liver there is no obvious separation of substrate and degrading system. On the contrary, given the continuous secretion of plasma proteins and uptake of proteins through endocytosis, there is continuous mixing or stirring of the cytoplasm. This is evident through membrane recycling (Tulkens, Schneider and Trovet, 1978 ; Millward, 1980b). Such a cytoplasmic mixing would increase the frequency of interaction of substrate and degrading system.

Thus the management by the nucleus of its functional cell would involve protein synthesis, occurring at a rate determined primarily by the amount of translational apparatus (eg. number of ribosomes, etc.), and protein degradation, occurring at a rate fixed by two factors, the amount and activity of the degradative system (the capacity for degradation), and the characteristic structure and function of the cytoplasm which determines the access or susceptibility of the protein to the degrading system. This latter factor determines a first-order rate so that during mitosis in liver or following the insertion of a new nucleus from a satellite cell in muscle, the functional cell size increases until the capacity for degradation is reached. In this way the concentration of the degrading system will be determined by the characteristics of the cellular structure and function. Thus the "proteolytic environment» or concentration of proteinases, previously described as the overall determinant of the rate of degradation in the cell (Waterlow, Garlick and Millward, 1978) would in this new model be determined by the overall degradation rate and not be a determinant of it. Of course, this emphasis on the cytoplasmic structure and function as a primary determinant of the overall degradation rate of a cell does not preclude regulatory changes in the activity of the degrading system which could then alter functional cell size. Furthermore, the actual structural and functional characteristics which determine the susceptibility of the cytoplasmic protein to degradation, particularly in muscle, have yet to be identified. This is an important task for the future.

\section{Conclusions.}

This paper has considered protein turnover both descriptively and from a more theoretical speculative aspect. In fact, the amount of firm experimental data on which 
each of these two aspects have been made is still very limited. However, data collection, which is still the major activity of those of us involved in the study of protein furnover, is of little value unless it can be gathered together in a rational way so that the biological phenomenon of protein turnover can be fully understood. It is hoped that the ideas expressed here help in that understanding.

6e Réunion du groupe Développement I.N.R.A., Clermont-Ferrand/Theix, 22-23 mai 1980.

Acknowledgments. - This work was supported by generous grants from the Muscular Dystrophy Group of Great Britain, the Medical Research Council and the British Council. The authors thank Dr. G. A. Clugston for making available data on whole body protein synthesis in man prior to publication.

Résumé. Le renouveliement des protéines $(R)$, résultat de la dégradation et du remplacement des protéines, varie dans la plupart des espèces adultes comme le poids métabolique $\left(P^{0}, 75\right)$, bien qu'il soit peut-être légèrement plus faible chez l'homme. Au cours du développement du rat il varie aussi comme l'intensité du métabolisme $\left(R\right.$ total $=14,7 \mathrm{P}^{0,53} \mathrm{~kg}$ par jour). La majeure partie de ce renouvellement des protéines a lieu dans les tissus autres que le muscle ( $R=11,3 P^{0,50} \mathrm{~kg}$ par jour) alors que la valeur du renouvellement des protéines

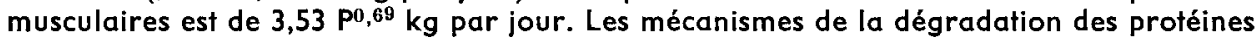
dans le foie et le muscle impliquent les lysosomes bien que la morphologie du système lysosomal musculaire soit différente de celle du foie. Cependant, un renouvellement hétérogène des protéines est une propriété des protéines de ces deux tissus, y compris les principales protéines myofibrillaires. Tandis que la synthèse des protéines peut être raisonnablement décrite par une réaction d'ordre « zéro » (une vitesse constante par unité de DNA) il y a moins de certitude pour la dégradation. Il est postulé que les caractéristiques structurales et fonctionnelles du cytoplasme des cellules déterminent l'accessibilité des protéines cellulaires au système de dégradation. Le résultat est une réaction d'ordre « un » pour un type cellulaire particulier et ceci détermine la taille du rapport protéine/DNA, c'est-à-dire la taille de la cellule « fonctionnelle ». La vitesse de dégradation d’ordre « un » des protéines cytoplasmiques détermine l'activité spécifique des enzymes de dégradation.

\section{References}

ARNAL M., FERRARA M., FAUCONNEAU G., 1976. Nuclear techniques in animal production and health. Int. atom. Energy Agency Rep. No. 205, 393-401.

BALLARD F. J., 1977. Intracellular protein degradation, 1-38. In CAMBELL P. N., ALDRIDGE W. N., Essays in Biochemisiry, vol. 13, Acad. Press.

BATES P. C., MILLWARD D. J., 1978. Changes in the relative rates of protein synthesis and breakdown during muscle growth and atrophy. Biochem. Soc. Trans., 6, 612.

BIRD J. W. C., CARTER J., TRIEMER R. E., BROOKS R. M., SPANIER A. M., 1980. Proteinases in cardiac and skeletal muscle. Fed. Proc., 39, 20-25.

BREIREM K., 1939. Der Energieumsatz bei den Schweinen. Tierernährung., 9, 487-528.

BROWN J. G., MILLWARD D. J., 1980. The influence of thyroid status on skeletal muscle protein metabolism. Biochem. Soc. Trans., 8, 366-367.

CAMBELL J. B., 1979. Quantitotive histochemical study of changes in acid phosphatase activity with age in normal and dystrophic skelefal muscle. M. Med. Sci. Thes., Univ. Dundee.

CHEEK D. B., HOLT A. B., HILL D. E., TALBERT J. C., 1971. Skeletal muscle cell mass and growth : the concept of the DNA-unit. Pediatr. Res., 5, 312-328. 
CHRISTIE K. N., STOWARD P. J., 1977. A cytochemical sfudy of acid phosphatase in dystrophic hamster muscle. J. ultrastruc. Res., 58, 219-234.

DEAN R. T., 1980. Protein degradation in cell culfures : general considerations on mechanisms and regulation. Fed. Proc., 39, 15-19.

FERRARA M., 1976. Synthèse protéique in vitro dans le muscle d'agneau au cours du développement. Défermination de la synthèse protéique du foie à l'aide du ${ }^{14} \mathrm{C}$ lysyl tRNA. Th. $3^{\mathrm{e}}$ cycle, Strasbourg.

GARLICK P. J., 1980. Protein turnover in the whole animal and specific tissues. In FLORKIN M., NEUBERGER A., VanDEENAN L. L. M., Comprehensive Biochemisiry, Vol. 19B (1), 77-152. Elsevier North-Holland, Biomed. Pres, Amsterdam.

GOLDBERG A. L., DICE J. F., 1974. Intracellular protein degradation in mammalian and bacterial cells. Ann. Rev. Biochem. 43, 835-869.

GOLDBERG A. L., ST. JOHN A. C., 1976. Intracellular protein degradation in mammalian and bacterial cells. Part 2. Ann. Rev. Biochem., 45, 747-804.

LAURENT G. J., MILLWARD D. J., 1980. Protein furnover during skeletal muscle hypertrophy. Fed. Proc. 39, 42-47.

LAURENT G. J., SPARROW M. P., MILLWARD D. J., 1978. Changes in rates of protein synthesis and breakdown during hypertrophy of the anterior and posterior latissimus dorsi muscles in the fowl. Biochem. J., 176, 407-417.

LOBLEY G. E., LOVIE J. M., 1979. The synthesis of myosin, actin and the major protein fractions in rabbit skeletal muscle. Biochem. J., 182, 867-874.

MARTINO G. N. de, GOLDBERG A. L., 1979. Identification and partial purification of an ATP. stimulated alkaline protease in rat liver. J. biol. Chem., 254, 3712-3715.

MARUYAMA K., SUNDE M. L., SWICK R. W., 1978. Growth and muscle protein turnover in the chick. Biochem. J., 176, 573-582.

MILLER S. A., 1968. Protein metabolism during growth and development, 180-236. In MUNRO H. N., Mammalian protein metabolism, Vol. 3, Acad. Press.

MILLWARD D. J., 1978. Regulation of muscle protein turnover in growth and development. Biochem. Soc. Trans., 6, 494-499.

MILLWARD D. J., 1980a. Protein furnover in skeletal and cardiac muscle during normal growth and hypertrophy, 161-191. In WILDENTHAL K. D., Degradative processes in heart and skeletal. muscle. Elsevier/North-Holland, Biomed. Press, Amsterdam.

MILLWARD D. J., 1980b. Protein degradation in muscle and liver. In FLORKIN M., NEUBERGER A. Van DEENAN L. L. M., Comprehensive Biochemistry, Vol. 19B (1) 153-232. Elsevier/North Holland, Amsterdam.

MILLWARD D. J., BATES P. C., BROWN J. T., ROSOCHAKI S. R., RENNIE M. J., 1980a. Prolein degradation and the regulation of protein balance in muscle, 302-329. In Protein degradation in health and disease, Ciba Found. Symp. 75.

MILLWARD D. J., BATES P. C., GRIMBLE G. K., BROWN J. G., NATHAN M., RENNIE M. J., $1980 b$. Quantitative importance of non-skeletal muscle sources of $\mathrm{N}$ methyl histidine. Biochem. $\int$. 190, 225-228.

MILLWARD D. J., GARLICK P. J., STEWART R. J. C., NNANYELUGO D. O., WATERLOW J. C., 1975, Skeletal muscle growth and protein turnover. Biochem. J., 150, 235-243.

MORKIN E. H., 1970. Postnatal muscle fibre assembly : localisation of newly synthesized myofibrillar proteins. Science, 167, 1499-1501.

MORTIMORE G. E., 1980. Liver perfusion : application of an in vitro model in studies of intracellular protein degradation, 288-306. In Protein degradation in health and disease. Ciba Found. Symp. 75.

NARAYAN N., EAPEN J., 1974. Protein synthesis in chick muscle during development. Ind. J. exp. Biol., 12, 340-342.

PAGE S. G., 1969. Structure and some contractile properties of fast and slow muscles of the chicken. J. Physiol., 205, 131-145.

REEDS S. G., LOBLEY G. E., 1980. Protein synthesis : are there real species differences ? Proc. Nutr. Soc., 39, 43-52.

ROSOCHAKI S. R., MILLWARD D. J., 1979. Cathepsin D and acid autolytic activity in skeletal muscle of protein deficient, severely protein-energy restricted, and refed rats. Proc. Nutr. Soc., 38, 137a.

SCHIMKE R. T., 1970. Regulation of protein degradation in mammalian tissues, 177-228. In MUNRO H. N., Mammalian protein metabolism, Vol. IV, Acad. Press. 
TALBOT F. B., 1938. Basal metabolic rates of man through development. Am. J. Dis. Child, 55, 455-462. TROUT J. J., STAUBER W. T., SCHOTTELIUS B. A., 1979. Cytochemical observations of two distinct acid phosphatase-reactive structures in anterior latissimus dorsi muscle of the chicken. Histochem. J., 11, 220-230.

TULKENS F., SCHNEIDER Y. J., TROUET A., 1978. A shuttle between the cell surface and lysosomes during endocytosis, 719-738. In SÉGAL H. L., DOYLE D. J., Protein turnover and lysosome function, Acad. Press, N. Y., London.

WALSH T. P., WINZOR D. J., CLARKE F. M., MASTERS C. !., MORTON D. J., 1980. Binding of aldolase to actin-containing filaments. Biochem. J., 186, 89-98.

WATERLOW J. C., GARLICK P. J., MILLWARD D. J., 1978. Profein turnover in mammalian tissues and in the whole body, Elsevier/North Holland, Biomed. Press, Amsterdam. 